\title{
U.S. International Transactions in 2000
}

Joseph E. Gagnon, of the Board's Division of International Finance, prepared this article. Chad Cleaver, Anthony Leegwater, and Nicholas Warren provided research assistance.

The U.S. current account deficit widened substantially in 2000 as the lagged effect of strong growth in the U.S. economy in late 1999 and early 2000 continued to drive up imports of goods and services faster than exports increased. To a lesser extent, a decline in U.S. price competitiveness also contributed to the expansion in the deficit.

Strong foreign economic growth supported a rapid increase of U.S. exports of both goods and services in 2000. However, U.S. imports of goods and services grew more than exports as U.S. gross domestic product (GDP) accelerated in late 1999 and the first half of 2000. Both U.S. and foreign GDP growth slowed sharply in the second half of 2000, but the lagged effect of the previous acceleration continued to widen the trade deficit. The real trade-weighted value of the dollar rose throughout the year, exerting a restraining influence on exports and helping to increase import demand. The net effect of these developments was an expansion in the goods and services trade deficit of more than $\$ 100$ billion in 2000 (table 1).

The investment income deficit decreased modestly in 2000 despite a growing net foreign liability position. Strong growth abroad and the effect of high oil prices on the profitability of U.S. energy companies raised the rate of return on U.S. foreign direct investment assets at the same time that the rate of return on U.S. direct investment liabilities fell slightly. The deficit on unilateral transfers continued to grow at a moderate pace.

The current account deficit reached a new record of nearly $4 \frac{1}{2}$ percent of U.S. GDP last year (chart 1 ). This deficit represents an excess of U.S. investment over U.S. saving of more than $\$ 400$ billion. In addition, almost $\$ 300$ billion of U.S. saving flowed abroad in the form of a continued increase in foreign direct and portfolio investment by U.S. residents. To finance the current account deficit and the capital outflow, the foreign private sector purchased a record amountmore than $\$ 700$ billion - of U.S. securities and direct investment assets. Continuing a trend that began in 1999, more than 100 percent of net foreign private securities purchases involved U.S. corporate bonds and stocks (including agency securities); the foreign

1. U.S. international transactions, 1996-2000

Billions of dollars except as noted

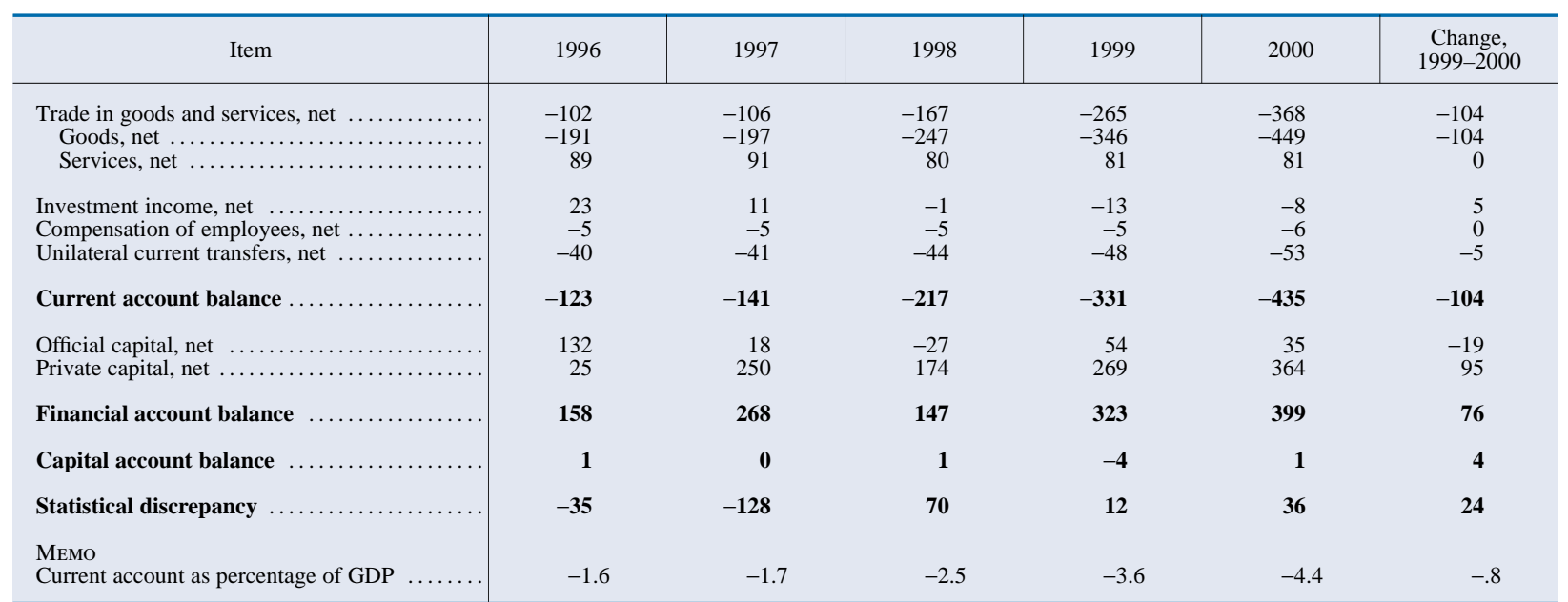

Note. In this and the tables that follow, components may not sum to totals because of rounding. 


\section{U.S. external balances, 1970-2000}

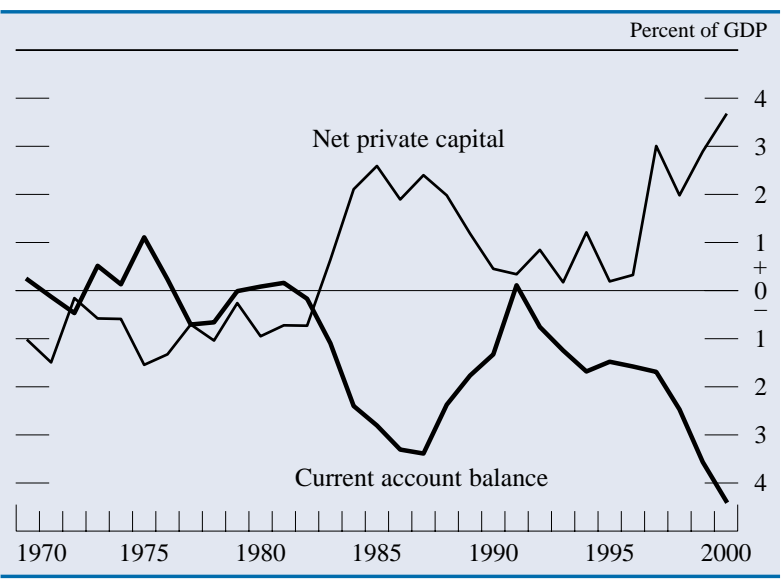

SOURCE. U.S. Department of Commerce, Bureau of Economic Analysis.

private sector was a net seller of U.S. Treasury securities. Net official inflows were down slightly from the moderate pace of 1999 .

\section{MAJOR ECONOMIC INFLUENCES ON U.S. INTERNATIONAL TRANSACTIONS}

Many factors influenced the U.S. current and financial accounts in 2000. The most important of these were the lagged effects of strong U.S. and foreign growth in late 1999 and early 2000, the sharp rise in oil prices in 1999 that continued into 2000, and a further appreciation of the dollar-following a pause in 1999—which built on earlier appreciations in 1997 and 1998.

\section{Foreign Economic Activity}

Following the slowdown of 1998, foreign growth increased through 1999 and peaked at a 51/2 percent annual rate in the first half of 2000 (table 2). In the second half of 2000, foreign growth slowed to 3 percent at an annual rate, and for the four quarters of 2000, foreign GDP grew 41/4 percent. The pattern of slowing from strong growth rates early in the year was shared on average by the industrial countries and by all major developing regions.

Among the major foreign industrial countries, the strongest performers in 2000 were Canada and Australia, which each grew 4 percent. The European Union grew almost 3 percent and Japan, 23/4 percent. Of these regions, the European Union exhibited the least slackening in growth during the course of last year.

In the foreign industrial countries, average inflation edged up to 3 percent, a result mainly of higher oil prices. During the first part of the year, monetary authorities moved to tighten conditions in many industrial countries in reaction to continued strong growth in economic activity that was starting to impinge on capacity constraints, as well as some upward pressures on prices. Interest rates on longterm government securities declined on balance in most industrial countries, especially toward year-end

2. Change in real GDP in the United States and abroad, 1997-2000

Percentage change, annual rate

\begin{tabular}{|c|c|c|c|c|c|c|c|c|c|}
\hline \multirow{2}{*}{ Area } & \multirow{2}{*}{1997} & \multirow{2}{*}{1998} & \multirow{2}{*}{1999} & \multirow{2}{*}{2000} & \multicolumn{5}{|c|}{ Half years } \\
\hline & & & & & 1998:H2 & 1999:H1 & 1999:H2 & 2000:H1 & 2000:H2 \\
\hline United States & 4.3 & 4.6 & 5.0 & 3.4 & 4.5 & 3.0 & 7.0 & 5.2 & 1.6 \\
\hline Total foreign ${ }^{1}$ & 4.3 & 1.2 & 4.8 & 4.2 & 1.8 & 4.5 & 5.1 & 5.5 & 2.9 \\
\hline Asian emerging markets 2 & 4.8 & -1.8 & 8.9 & 6.3 & 2.6 & 9.6 & 8.2 & 7.7 & 4.8 \\
\hline China & 8.2 & 9.5 & 6.2 & 7.4 & 12.4 & 1.7 & 11.0 & 5.7 & 9.2 \\
\hline Indonesia & 1.2 & -18.2 & 5.8 & 5.3 & -8.8 & 14.0 & -1.8 & 12.7 & -1.7 \\
\hline Korea & 3.4 & -5.2 & 13.8 & 5.2 & 6.9 & 15.2 & 12.4 & 6.5 & 3.9 \\
\hline Malaysia & 6.3 & -11.1 & 11.0 & 6.5 & -5.4 & 16.5 & 5.9 & 11.0 & 2.3 \\
\hline Philippines & 5.0 & -2.0 & 5.1 & 3.6 & .9 & 6.3 & 3.8 & 4.9 & 2.3 \\
\hline Taiwan .... & 7.0 & 3.4 & 6.5 & 4.1 & 3.9 & 8.9 & 4.2 & 6.7 & 1.6 \\
\hline Latin America ${ }^{3}$ & 6.1 & 1.2 & 4.3 & 4.7 & -.5 & 3.0 & 5.6 & 7.4 & 2.1 \\
\hline Argentina ... & 7.6 & -.5 & -.6 & -2.0 & -6.2 & -4.1 & 3.2 & -2.8 & -1.3 \\
\hline Brazil .... & 2.4 & -.8 & 3.4 & 4.3 & -4.0 & 3.5 & 3.4 & 3.8 & 4.8 \\
\hline Mexico & 6.7 & 2.8 & 5.5 & 5.2 & 2.4 & 4.5 & 6.4 & 8.7 & 1.7 \\
\hline Venezuela & 6.7 & -4.7 & -4.1 & 5.5 & -10.3 & -4.6 & -3.7 & 9.5 & 1.7 \\
\hline Canada & 4.8 & 3.2 & 4.9 & 4.0 & 4.5 & 4.1 & 5.8 & 4.5 & 3.5 \\
\hline European Union .. & 3.1 & 2.1 & 3.4 & 2.9 & 1.7 & 2.6 & 4.1 & 3.3 & 2.5 \\
\hline Japan ............ & .7 & -1.4 & .4 & 2.8 & -1.9 & 4.1 & -3.1 & 5.4 & .4 \\
\hline
\end{tabular}

NotE. Aggregate measures are weighted by moving bilateral shares in U.S. exports of nonagricultural merchandise. Annual data are four-quarter changes. Half-yearly data are calculated as Q4/Q2 or Q2/Q4 changes at an annual rate. 1. Selected regions and economies are shown below.

2. Weighted average of China, Hong Kong, Indonesia, Korea, Malaysia, Philippines, Singapore, Taiwan, and Thailand.

3. Weighted average of Mexico, Argentina, Brazil, Chile, Colombia, and Venezuela.

SOURCE. Various national sources. 
when evidence of a slowdown in global economic growth started to emerge.

The improvement in overall fiscal positions of the major industrial countries continued during 2000. Partly as a result of one-time revenues from the sale of mobile telephone licenses, the general government balance of the euro area moved into surplus. The Canadian surplus is estimated to have been $2 \frac{1}{2}$ percent of GDP last year. Even in Japan, where the deficit is estimated to have been nearly $6 \frac{1}{2}$ percent of GDP in 2000, there has been some movement toward fiscal consolidation.

The experiences of major Latin American countries were mixed in 2000. Brazil enjoyed relatively strong growth as a result of lower domestic nominal and real interest rates. Mexico began 2000 with extremely strong growth rates supported by high oil prices, but growth slowed sharply in the second half, in response partly to tighter monetary policy and partly to slower growth in the United States late in the year. Strong oil prices also supported a return to growth in Venezuela last year. In contrast, Argentina's economy contracted substantially in 2000 after a stagnant 1999. The Argentine government continued to struggle to put policies in place that would bolster market confidence and support recovery.

Growth in Asian developing economies slowed sharply during 2000, with the principal exception of China. To a large extent, this pattern reflects the importance of high-technology exports to the United States and the slackening in U.S. high-tech imports late in the year. Another contributing factor to the Asian slowdown may have been the sustained high price of imported oil. Finally, specific factors in individual economies played a role in holding down growth, including a resurgence of corporaterestructuring problems in Korea and heightened political uncertainty in Indonesia, the Philippines, and Taiwan.

\section{U.S. Economic Activity}

After expanding briskly in the first half, the U.S economy decelerated dramatically in the second half of 2000. For the year as a whole, GDP increased $3 \frac{1}{2}$ percent (table 2). The major contributor to the deceleration was business investment in equipment and software, which slowed in the third quarter and contracted in the fourth. The high-tech sector was especially hard hit, but slowing growth in business output, rising energy costs, and falling profits took their toll on business expenditures on motor vehicles and other types of equipment as well.
2. Oil prices, 1985-2000

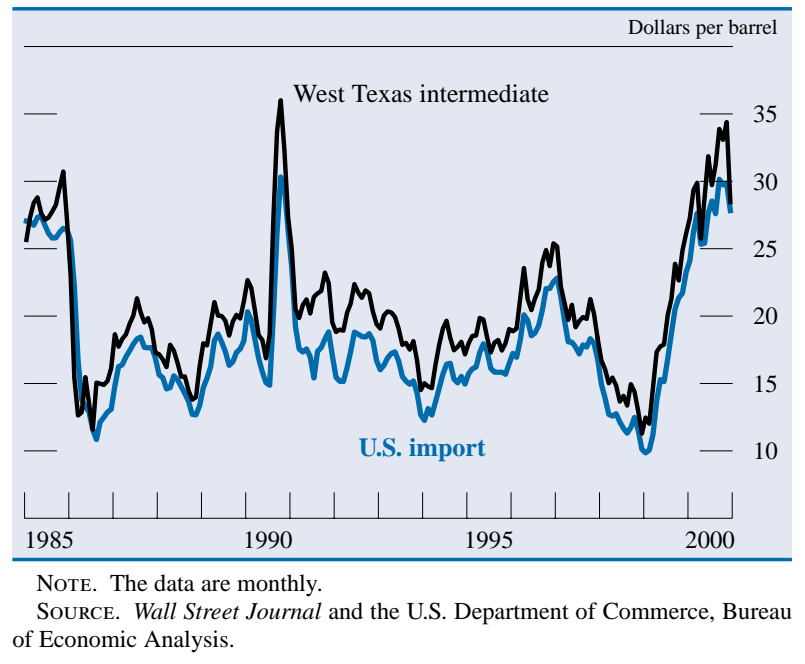

Household spending on services advanced at a rapid pace throughout the year. But spending on goods stagnated in the second half, in part because of an outright decline in motor vehicle sales. The sluggish pace of consumer spending was likely linked to a less favorable labor market situation, decelerating real personal income, and the waning of positive wealth effects from previous stock price increases. In addition, there was probably some rebound from the strong light vehicle purchases in 1999 and early 2000. Businesses were apparently caught off guard by the slowing in final sales last year, and inventories built up, leaving inventory-sales ratios elevated at year-end. Housing starts declined from a very high level at the beginning of the year before flattening out as falling mortgage rates balanced the restraining effects of a leveling-off of household wealth.

Real government spending rose only 1 percent over the four quarters of 2000. Federal purchases declined after a surge in spending in late 1999 due to Y2K concerns. State and local government purchases posted only a modest gain, as spending on investment slowed from its rapid 1999 pace. The general government surplus rose to $2 \frac{1 / 4}{4}$ percent of GDP for the year as a whole.

\section{Oil and Other Primary Commodity Prices}

The phrase "high and volatile" best describes oil prices during 2000. The spot price of West Texas intermediate, the U.S. benchmark crude, fluctuated between \$24 and \$37 per barrel last year and reached levels not seen since the Gulf War in 1991 (chart 2). Relatively high oil prices persisted throughout the 
3. Prices of world non-oil primary commodities, 1985-2000

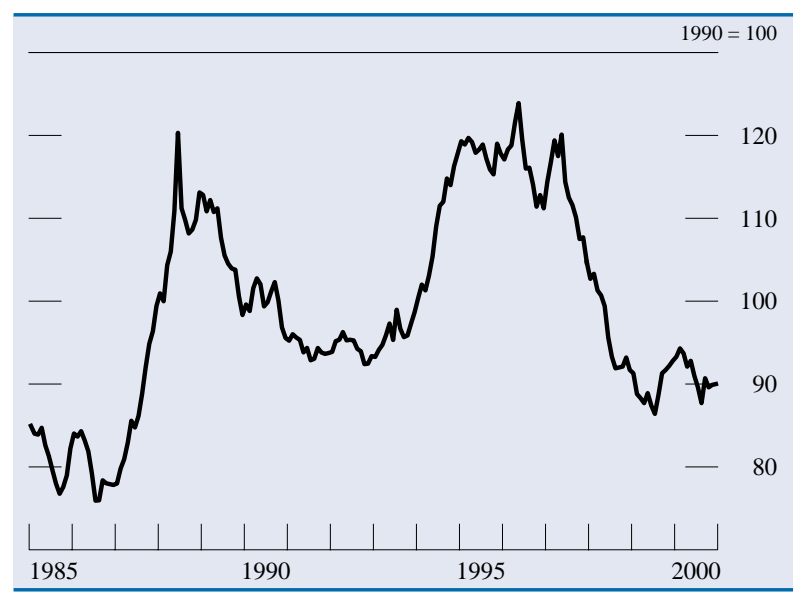

Note. The data are monthly.

Source. International Monetary Fund, International Financial Statistics, index of non-oil commodity prices in dollars.

year as a result of demand spurred by strong global economic growth. The underlying strength of world oil demand was apparent: Oil prices remained elevated even as world oil production increased sharply. Most of the expansion in production came from the Organization of Petroleum Exporting Countries (OPEC), which reversed the production restraints that had been implemented in the previous two years. Non-OPEC production rebounded as well, led notably by increases in the former Soviet Union.

The unusual volatility of oil prices during 2000 was the consequence of historically low levels of crude oil and petroleum product inventories in the United States and abroad. With little scope for changes in inventories to accommodate fluctuations in supply and demand, large and rapid swings in oil prices were common. For example, in September as the spot price of West Texas intermediate approached its high for the year, the U.S. government authorized a release of 30 million barrels from the Strategic Petroleum Reserve, and oil prices declined about $\$ 7$ per barrel within a few days. Oil prices soon reversed this decline, however, but then fell $\$ 10$ per barrel during the last two months of the year as evidence mounted that U.S. economic growth was slowing.

Prices of non-oil primary commodities resumed their decline last year, following a modest uptick in late 1999 (chart 3). From 1997 through the first half of 1999, weak global demand, combined with a large supply increase in response to the high prices of the mid-1990s (especially for agricultural products), put severe downward pressure on commodity prices. Reduced supplies and the recovery in global eco- nomic activity reversed this decline, and prices strengthened in the second half of 1999. The combination of the strength of the dollar and the slowdown in global economic growth led prices of non-oil primary commodities to resume their decline in mid2000. By the end of last year, the decline in prices was particularly evident in the cyclically sensitive commodities-metals and agricultural raw materials.

\section{U.S. Price Competitiveness}

Over 2000, non-energy price increases remained subdued in the United States and in most of its trading partners. As is usually the case, the major factor contributing to gains and losses in U.S. international price competitiveness has been the exchange value of the dollar. After remaining flat in 1999, the real trade-weighted exchange value of the dollar in terms of an index of a broad group of U.S. trading partners appreciated $7 \frac{1}{2}$ percent over the four quarters of 2000. As of year-end, the broad dollar index had appreciated 27 percent from its previous low point in July 1995 (chart 4).

The dollar's movements last year differed significantly across the trading partners of the United States. The dollar appreciated (in real terms) 20 percent against the euro, 14 percent against the pound, 10 percent against the yen, and 4 percent against the Canadian dollar. The dollar's appreciation against the euro in 2000 followed an appreciation during 1999 of

\section{Foreign exchange value of the U.S. dollar, 1990-2000}

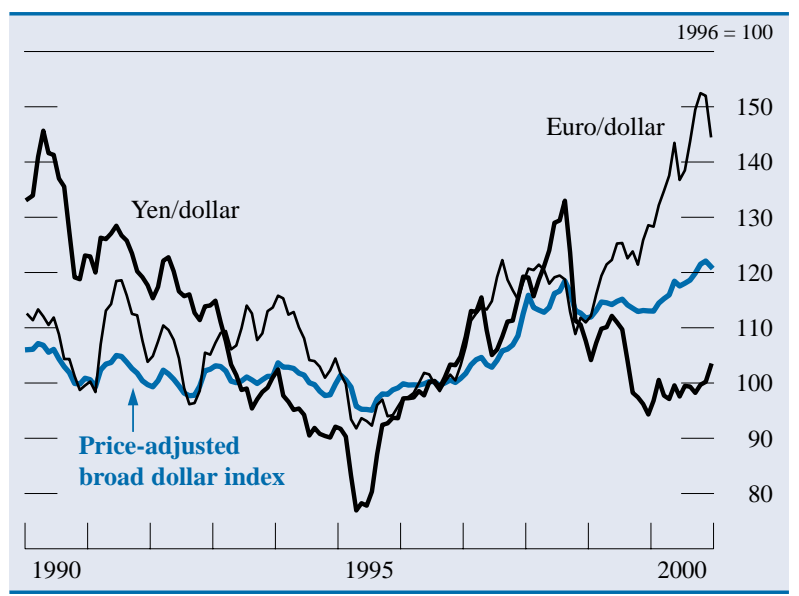

NoTE. The broad dollar index included thirty-five currencies until the beginning of stage three of European Economic and Monetary Union on January 1, 1999, when the euro replaced the ten euro-area currencies; the broad dollar index now has twenty-six currencies. Currencies of all foreign countries or regions that had a share of U.S. non-oil imports or nonagricultural exports of at least $1 / 2$ percent in 1997 are included in the broad dollar index. The data for the euro use the restated German mark before January 1999. The data are monthly. 
nearly 15 percent, and it persisted despite year-end evidence that the U.S. economy had slowed to a rate of growth below that of Europe. Against a weighted average of developing country trading partners, the dollar appreciated just over 2 percent in real terms during 2000. A number of developing countries have significantly higher inflation rates than the United States, so that their currencies tend to appreciate against the dollar in real terms even when the nominal exchange rate is constant or slowly depreciating. For example, the Mexican peso appreciated nearly 5 percent against the dollar in real terms last year, primarily because of higher inflation in Mexico.

\section{DEVELOPMENTS IN U.S. TRADE IN GOODS AND SERVICES}

The U.S. trade deficit in goods and services was substantially larger in 2000 than in 1999 (table 3). The steep decline in the external balance reflected the lagged effects on imports of robust economic growth in the United States early in the year and the increasing price competitiveness of foreign goods as the dollar appreciated; together these factors outweighed the pull on exports of generally strong economic growth abroad during the first three quarters of 2000.

\section{Exports}

The value of exports of goods and services rose $\$ 113$ billion in 2000 after a very small increase in 1999 (table 3). Receipts from services rose 9 percent, more than twice the rate recorded in 1999, with much of the increase recorded in receipts from foreign travelers in the United States and "other private services" (mostly business, professional, technical, and financial services). Sales of military equipment declined slightly as did receipts from other government services.

The value of goods exports expanded 13 percent after a marginal increase in 1999. Capital equipment

3. U.S. international trade in goods and services, 1997-2000 Billions of dollars except as noted

\begin{tabular}{|c|c|c|c|c|c|c|c|c|}
\hline \multirow{2}{*}{ Item } & \multirow{2}{*}{1997} & \multirow{2}{*}{1998} & \multirow{2}{*}{1999} & \multirow{2}{*}{2000} & \multicolumn{3}{|c|}{ Dollar change } & \multirow{2}{*}{$\begin{array}{c}\text { Percentage } \\
\text { change, } \\
1999 \text { to } 2000\end{array}$} \\
\hline & & & & & 1997 to 1998 & 1998 to 1999 & 1999 to 2000 & \\
\hline Balance on goods and services & -106 & -167 & -265 & -368 & -61 & -98 & -104 & $\cdots$ \\
\hline Exports of goods and services & 937 & 933 & 956 & 1,070 & -4 & 23 & 113 & 12 \\
\hline $\begin{array}{l}\text { Services } \ldots \ldots \ldots \ldots \ldots \ldots \ldots \\
\text { Goods } \ldots \ldots \ldots \ldots \ldots \ldots \ldots\end{array}$ & $\begin{array}{l}257 \\
680\end{array}$ & $\begin{array}{l}263 \\
670\end{array}$ & $\begin{array}{l}272 \\
684\end{array}$ & $\begin{array}{l}296 \\
773\end{array}$ & $\begin{array}{r}5 \\
-9\end{array}$ & $\begin{array}{r}9 \\
14\end{array}$ & $\begin{array}{l}24 \\
89\end{array}$ & $\begin{array}{r}9 \\
13\end{array}$ \\
\hline $\begin{array}{l}\text { Agricultural products } \ldots \ldots \ldots \ldots \ldots \ldots \ldots \\
\text { Nonagricultural goods } \ldots \ldots \ldots \ldots \ldots \ldots\end{array}$ & $\begin{array}{r}58 \\
621\end{array}$ & $\begin{array}{r}53 \\
617\end{array}$ & $\begin{array}{r}50 \\
635\end{array}$ & $\begin{array}{r}53 \\
720\end{array}$ & $\begin{array}{l}-5 \\
-4\end{array}$ & $\begin{array}{r}-3 \\
18\end{array}$ & $\begin{array}{r}4 \\
85\end{array}$ & $\begin{array}{r}7 \\
13\end{array}$ \\
\hline $\begin{array}{r}\text { Capital equipment } \ldots \ldots \ldots \ldots \ldots \ldots \ldots \\
\text { Aircraft and parts } \ldots \ldots \ldots \ldots \ldots \ldots \ldots \\
\text { Computers, peripherals, and parts .. } \\
\text { Semiconductors } \ldots \ldots \ldots \ldots \ldots \ldots \\
\text { Telecommunications equipment } \ldots \\
\text { Other machinery and equipment } \ldots\end{array}$ & $\begin{array}{r}296 \\
41 \\
49 \\
39 \\
24 \\
142\end{array}$ & $\begin{array}{r}300 \\
54 \\
45 \\
38 \\
25 \\
139\end{array}$ & $\begin{array}{r}312 \\
53 \\
47 \\
47 \\
27 \\
139\end{array}$ & $\begin{array}{r}357 \\
48 \\
56 \\
60 \\
33 \\
161\end{array}$ & $\begin{array}{r}4 \\
12 \\
-4 \\
-1 \\
1 \\
-3\end{array}$ & $\begin{array}{r}12 \\
-1 \\
1 \\
9 \\
2 \\
0\end{array}$ & $\begin{array}{r}45 \\
-5 \\
9 \\
13 \\
6 \\
22\end{array}$ & $\begin{array}{r}14 \\
-9 \\
19 \\
28 \\
22 \\
16\end{array}$ \\
\hline $\begin{array}{l}\text { Industrial supplies } \ldots \ldots \ldots \ldots \ldots \ldots \ldots \\
\text { Automotive products } \ldots \ldots \ldots \ldots \ldots \ldots \ldots \\
\text { Consumer goods } \ldots \ldots \ldots \ldots \ldots \ldots \ldots \\
\text { Other nonagricultural exports } \ldots \ldots \ldots\end{array}$ & $\begin{array}{r}148 \\
74 \\
77 \\
26\end{array}$ & $\begin{array}{r}138 \\
73 \\
79 \\
26\end{array}$ & $\begin{array}{r}139 \\
76 \\
81 \\
27\end{array}$ & $\begin{array}{r}163 \\
80 \\
89 \\
31\end{array}$ & $\begin{array}{r}-9 \\
-1 \\
2 \\
0\end{array}$ & $\begin{array}{l}1 \\
3 \\
2 \\
1\end{array}$ & $\begin{array}{r}24 \\
4 \\
8 \\
4\end{array}$ & $\begin{array}{r}17 \\
6 \\
10 \\
15\end{array}$ \\
\hline Imports of goods and services & 1,043 & 1,100 & 1,221 & 1,438 & 57 & 121 & 217 & 18 \\
\hline $\begin{array}{l}\text { Services } \ldots \ldots \ldots \ldots \ldots \ldots \ldots \ldots \ldots \ldots \\
\text { Goods } \ldots \ldots \ldots \ldots \ldots \ldots \ldots \ldots \ldots \ldots \ldots\end{array}$ & $\begin{array}{l}167 \\
876\end{array}$ & $\begin{array}{l}183 \\
917\end{array}$ & $\begin{array}{r}191 \\
1,030\end{array}$ & $\begin{array}{r}215 \\
1,223\end{array}$ & $\begin{array}{l}16 \\
41\end{array}$ & $\begin{array}{r}9 \\
113\end{array}$ & $\begin{array}{r}24 \\
193\end{array}$ & $\begin{array}{l}13 \\
19\end{array}$ \\
\hline $\begin{array}{l}\text { Oil } \ldots \ldots \ldots \ldots \ldots \ldots \ldots \ldots \ldots \\
\text { Non-oil } \ldots \ldots \ldots \ldots \ldots \ldots \ldots \ldots\end{array}$ & $\begin{array}{r}72 \\
805\end{array}$ & $\begin{array}{r}51 \\
866\end{array}$ & $\begin{array}{r}68 \\
962\end{array}$ & $\begin{array}{r}120 \\
1,102\end{array}$ & $\begin{array}{r}-21 \\
62\end{array}$ & $\begin{array}{l}17 \\
96\end{array}$ & $\begin{array}{r}52 \\
140\end{array}$ & $\begin{array}{l}77 \\
15\end{array}$ \\
\hline $\begin{array}{r}\text { Capital equipment } \ldots \ldots \ldots \ldots \ldots \ldots \ldots \\
\text { Aircraft and parts ................... } \\
\text { Computers, peripherals, and parts .. } \\
\text { Semiconductors .................. } \\
\text { Telecommunications equipment ... } \\
\text { Other machinery and equipment ... }\end{array}$ & $\begin{array}{r}253 \\
17 \\
70 \\
37 \\
15 \\
115\end{array}$ & $\begin{array}{r}270 \\
22 \\
72 \\
33 \\
17 \\
125\end{array}$ & $\begin{array}{r}297 \\
24 \\
81 \\
38 \\
24 \\
130\end{array}$ & $\begin{array}{r}352 \\
26 \\
90 \\
48 \\
38 \\
150\end{array}$ & $\begin{array}{r}16 \\
5 \\
2 \\
-3 \\
2 \\
10\end{array}$ & $\begin{array}{r}28 \\
2 \\
9 \\
4 \\
7 \\
6\end{array}$ & $\begin{array}{r}55 \\
3 \\
8 \\
11 \\
14 \\
19\end{array}$ & $\begin{array}{l}19 \\
11 \\
10 \\
28 \\
59 \\
15\end{array}$ \\
\hline $\begin{array}{l}\text { Industrial supplies } \ldots \ldots \ldots \ldots \ldots \ldots \ldots \\
\text { Automotive products } \ldots \ldots \ldots \ldots \ldots \ldots \ldots \\
\text { Consumer goods } \ldots \ldots \ldots \ldots \ldots \ldots \ldots \\
\text { Food and other goods } \ldots \ldots \ldots \ldots \ldots \ldots\end{array}$ & $\begin{array}{r}146 \\
140 \\
194 \\
72\end{array}$ & $\begin{array}{r}152 \\
149 \\
217 \\
79\end{array}$ & $\begin{array}{r}157 \\
179 \\
240 \\
89\end{array}$ & $\begin{array}{r}181 \\
196 \\
276 \\
97\end{array}$ & $\begin{array}{r}7 \\
9 \\
23 \\
7\end{array}$ & $\begin{array}{r}5 \\
30 \\
23 \\
10\end{array}$ & $\begin{array}{r}24 \\
17 \\
36 \\
8\end{array}$ & $\begin{array}{r}15 \\
9 \\
15 \\
9\end{array}$ \\
\hline
\end{tabular}




\section{Structural Change in U.S. Export Markets}

In recent years, U.S. goods exports have grown faster than would have been predicted by historical relationships based on foreign GDP growth and relative prices. Examination of the pattern of U.S. export growth across destination markets suggests that this acceleration of goods exports is the result of trade liberalization and the opening of markets abroad.

Chart 5 displays U.S. goods exports as a share of GDP in five major markets: Australia, Canada, the European Union, Japan, and Mexico, which together account for nearly 70 percent of total U.S. goods exports. The data are normalized so that the U.S. export share of destination market GDP is 100 in 1990. This normalization allows us to compare changes in market penetration over time. To a reasonable approximation, changes in foreign GDP and real exchange rates should not affect market penetration in nominal terms. ${ }^{1}$

1. If the income and price elasticities of foreign demand for U.S. exports are both equal to one, then the market penetration ratio is constant except for structural change and (relatively minor) lagged volume adjustments. Estimates of the income and price elasticities of U.S. goods exports are typically close to one. See, for example, the long-run and short-run estimates in Peter Hooper, Karen Johnson, and Jaime Marquez, "Trade Elasticities for the G-7 Countries," Princeton Studies in International Economics No. 87, Princeton University, August 2000.
Chart 5 shows that U.S. exports to Canada and Mexico have increased much faster than Canadian and Mexican GDP. We attribute this structural change to the U.S.Canadian Free Trade Agreement of 1989 and to the North American Free Trade Agreement of 1994. Apparently, barriers to U.S. exports have fallen substantially in these countries, and U.S. businesses have taken advantage of the opportunities created.

The data for exports to Australia and Japan provide little evidence of structural change in the 1990s. However, U.S. exports to the European Union have increased much faster than European GDP in the past four years. This development raises the intriguing possibility that the European Single Market initiative of 1992 and the establishment of European Economic and Monetary Union in 1999 have increased the attractiveness of the European market for U.S. exporters.

This study and other studies have found a higher estimate of the income elasticity of U.S. goods imports, typically around two, compared with one for exports. The source of this higher import elasticity is not clear, but it implies that U.S. imports tend to grow faster than U.S. exports even when the U.S. economy grows at the same rate as that of the rest of the world. and industrial supplies accounted for most of the growth in goods exports. There were strong increases in high-tech equipment, such as computers, semiconductors, and telecommunications equipment, as well as in other machinery, such as power-generating, industrial, and service equipment. Increases in exported industrial supplies were spread widely among categories and were especially strong in

5. U.S. bilateral export values relative to destination GDP, 1990-2000

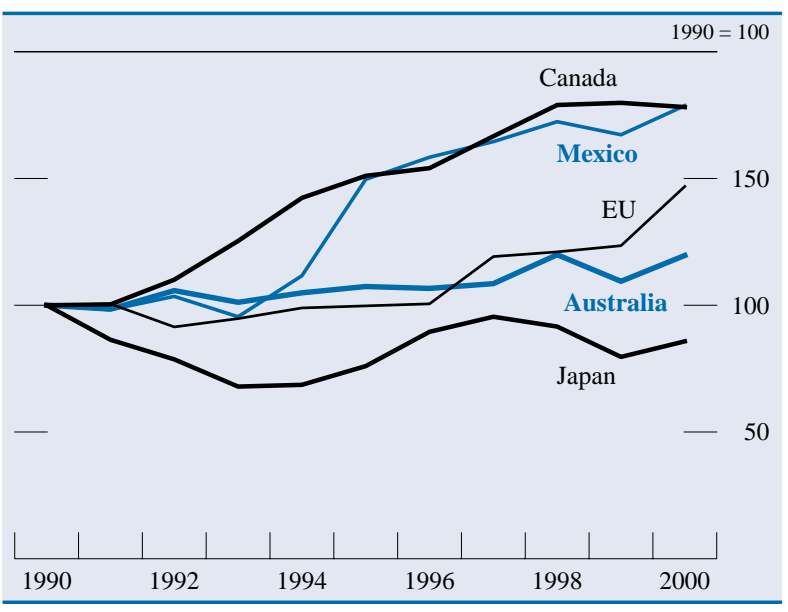

Source. U.S. Department of Commerce, Bureau of Economic Analysis; various national sources. petroleum products, steel, other metals, paper, chemicals, and textiles. There was a smaller expansion in exports of automotive products, consumer goods, and agricultural products. Exports of aircraft and parts declined moderately in 2000.

Although goods exports rose strongly during much of the year, in the fourth quarter most categories of exports fell. This reduction coincided with a sharp slowing of growth rates both in the United States and abroad. The U.S. slowdown contributed to the fourthquarter decline in exports because a large fraction of U.S. high-tech and automotive exports are processed abroad and returned to the United States for final sale.

Reflecting the strength of economic activity in North America for most of the year, U.S. exports to Canada and Mexico advanced rapidly in the first three quarters of 2000. This growth in exports to Canada and Mexico continues a pattern evident since the 1994 North American Free Trade Agreement of stronger-than-expected exports to these countries (see box). Exports to Mexico rose $\$ 25$ billion in 2000, or nearly 30 percent, with increases spread over all major categories of trade (table 4). Capital equipment exports to Mexico made up more than 35 percent of the total, and industrial supplies, nearly 30 percent. Automotive products (largely parts) accounted for 15 percent of exports to Mexico. Exports to Canada 
expanded $\$ 12$ billion, or 7 percent. Increases were largely in capital equipment and industrial supplies. Automotive products (one-fourth of U.S. exports to Canada) declined in 2000 , primarily in the second half of the year.

Exports of goods to Asian emerging markets grew $\$ 24$ billion in 2000, or 23 percent. Almost all of the increase was in capital goods (particularly high-tech equipment), which accounted for 60 percent of U.S. exports to that region. After gaining strength in the first three quarters, exports to this region accounted for much of the decline in total U.S. exports in the fourth quarter. Exports to Japan followed a more muted pattern, rising moderately through the third quarter before leveling off in the fourth quarter.

The value of exports to Western Europe rose strongly in 2000, following several years of lackluster performance, as economic growth picked up in the area. Capital equipment constituted nearly 55 percent of U.S. exports to Western Europe in 2000, and industrial supplies another 20 percent. In contrast to most other regions, exports to Western Europe continued to rise in the fourth quarter, even as total U.S. goods exports declined.

The quantity of exports rose 7 percent in 2000 (Q4/Q4), substantially faster than in the previous two years (table 5). Increases were spread across most major categories of trade, with the exception of aircraft exports, which declined.

Prices of goods exports rose $3 / 4$ percent in 2000 (table 6). When computers, semiconductors, and agricultural products are excluded, the increase in the index for export prices was larger, $13 / 4$ percent, which

4. U.S. exports of goods to its major trading partners, 1997-2000

Billions of dollars

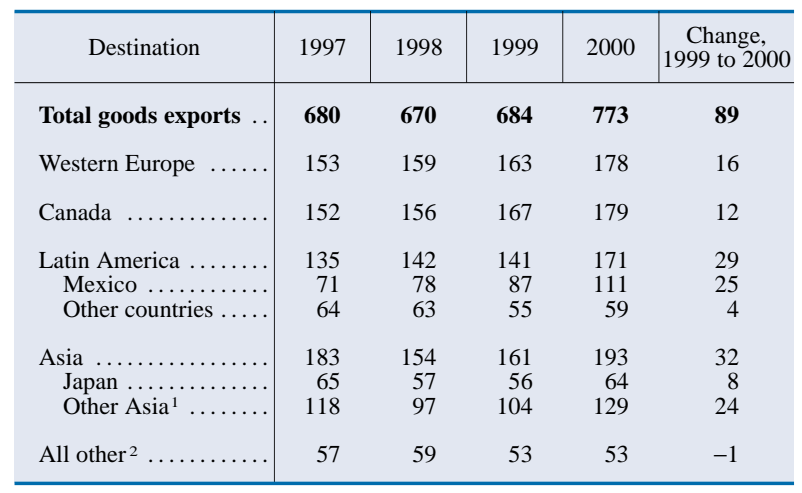

1. Includes China, Hong Kong, Singapore, Taiwan, Indonesia, Philippines, Malaysia, and Thailand.

2. Includes Australia, New Zealand, Middle East, Eastern Europe, and Africa.

SoURCE. U.S. Department of Commerce, Bureau of Economic Analysis, U.S. international transactions accounts.
5. Change in the quantity of U.S. exports and imports of goods and services, 1997-2000

Percent, fourth quarter to fourth quarter

\begin{tabular}{|c|c|c|c|c|}
\hline Item & 1997 & 1998 & 1999 & 2000 \\
\hline Exports of goods and services & 9 & 2 & 4 & 7 \\
\hline Services & 1 & 3 & 0 & 3 \\
\hline Goods & 12 & 2 & 6 & 8 \\
\hline Capital equipment & 18 & 5 & 7 & 13 \\
\hline Aircraft and parts & 8 & 49 & -18 & -14 \\
\hline Computers, peripherals, and parts & 26 & 7 & 13 & 24 \\
\hline Semiconductors . & 21 & 9 & 34 & 27 \\
\hline Other machinery and equipment & 17 & -8 & 7 & 15 \\
\hline Industrial supplies & 6 & -3 & 6 & 7 \\
\hline Automotive vehicles and parts & 14 & -2 & 3 & 0 \\
\hline Consumer goods & 7 & 1 & 6 & 6 \\
\hline Agricultural products & 1 & 0 & 0 & 7 \\
\hline Imports of goods and services & 14 & 11 & 12 & 11 \\
\hline Services & 14 & 9 & 2 & 13 \\
\hline Goods & 14 & 12 & 14 & 11 \\
\hline Oil & 4 & 5 & -4 & 13 \\
\hline Non-oil & 15 & 12 & 15 & 11 \\
\hline Capital equipment & 25 & 11 & 19 & 20 \\
\hline Aircraft and parts ..... & 26 & 31 & -2 & 23 \\
\hline Computers, peripherals, & & & & \\
\hline Semiconductors & 33 & -7 & 34 & 23 \\
\hline Other machinery and & & & & \\
\hline equipment & 17 & 6 & 17 & 21 \\
\hline Industrial supplie & 7 & 9 & 9 & 1 \\
\hline Automotive vehicles and parts & 8 & 16 & 15 & 2 \\
\hline Consumer goods & 14 & 10 & 15 & 14 \\
\hline Foods, feeds, and beverages & 9 & 5 & 11 & 7 \\
\hline
\end{tabular}

NoTE. Quantities are measured in chained (1996) dollars.

SouRCE. U.S. Department of Commerce, Bureau of Economic Analysis, national income and product accounts; and the Federal Reserve Board.

was about the same rate as in 1999. Stronger growth in prices of exported industrial supplies and aircraft was moderated by small rises in prices of other machinery and automotive products. Prices of agricultural exports declined $1 / 2$ percent, the smallest rate of decrease in four years. Prices of computers and semiconductors (measured by hedonic indexes) continued to decline.

\section{Imports}

The value of imports grew 18 percent in 2000, nearly twice as fast as in 1999, with increases recorded in all major categories of trade (table 3). The expansion of imports was fueled by the sharp growth of U.S. domestic expenditures throughout most of the year, the increasing price competitiveness of foreign goods as the dollar appreciated, and the rise in the price of imported oil. Oil and capital equipment each accounted for one-quarter of the rise in imports; consumer goods accounted for another 17 percent; 
6. Change in prices of U.S. exports and imports of goods and services, 1997-2000

Percent, fourth quarter to fourth quarter

\begin{tabular}{|c|c|c|c|c|}
\hline Item & 1997 & 1998 & 1999 & 2000 \\
\hline Total exports of goods and services & -.8 & -2.6 & 1.0 & 1.3 \\
\hline Services & .8 & -.2 & 2.9 & 2.6 \\
\hline Goods ..... & -1.5 & -3.5 & .3 & .7 \\
\hline Agricultural products & -3.2 & -10.1 & -5.1 & -.5 \\
\hline Nonagricultural goods .... & -1.3 & -2.9 & .7 & .8 \\
\hline $\begin{array}{c}\text { Computers, peripherals, } \\
\text { and parts }\end{array}$ & -11.0 & -12.7 & -6.9 & -4.4 \\
\hline Semiconductors $\ldots \ldots \ldots$ & -13.3 & -5.6 & -3.6 & -4.3 \\
\hline Other goods ..... & .6 & -1.9 & 1.7 & 1.8 \\
\hline Industrial supplies & -.5 & -7.3 & 4.1 & 4.0 \\
\hline Aircraft $\ldots \ldots \ldots \ldots$ & 2.6 & 1.2 & 2.6 & 4.5 \\
\hline Other machinery & 1.2 & -.1 & .3 & .7 \\
\hline Automotive products & .7 & .4 & .8 & 6 \\
\hline Consumer goods.... & .8 & -.5 & .1 & .0 \\
\hline Total imports of goods and services & -4.2 & -5.0 & 3.6 & 2.4 \\
\hline Services & -2.3 & -.4 & 3.2 & -1.2 \\
\hline Goods . & -4.6 & -5.9 & 3.7 & 3.1 \\
\hline Oil & -20.2 & -35.7 & 93.6 & 31.9 \\
\hline Non-oil & -2.8 & -3.6 & -.7 & .6 \\
\hline $\begin{array}{c}\text { Computers, peripherals, } \\
\text { and parts } \ldots \ldots \ldots \ldots\end{array}$ & -14.8 & -16.4 & -106 & -6.1 \\
\hline Semiconductors .......... & $\begin{array}{l}-14.0 \\
-14.9\end{array}$ & $\begin{array}{r}-10.4 \\
-8.2\end{array}$ & $\begin{array}{r}-10.0 \\
-2.7\end{array}$ & $\begin{array}{l}-0.1 \\
-2.9\end{array}$ \\
\hline Other goods ... & -.8 & -2.0 & .4 & 1.4 \\
\hline Industrial supplies & -.1 & -6.8 & 4.3 & 10.6 \\
\hline Aircraft & 3.4 & 1.7 & 1.6 & 3.4 \\
\hline Other machinery & -3.2 & -1.3 & -1.6 & -1.1 \\
\hline Automotive products & .6 & -.3 & .9 & .7 \\
\hline Consumer goods ....... & -1.3 & -1.2 & -.6 & -1.1 \\
\hline Foods, feeds, and beverages & .1 & -3.0 & -3.1 & -2.4 \\
\hline
\end{tabular}

SourcE. U.S. Department of Commerce, Bureau of Economic Analysis, national income and product accounts; chain-weighted indexes; and the Federal Reserve Board.

and automotive products, industrial supplies, and services each accounted for about 10 percent.

\section{Oil Imports}

The quantity of U.S. imports of crude oil and petroleum products increased 13 percent over the four quarters of 2000. Despite robust economic growth through the first half of the year, U.S. final demand for oil was essentially unchanged from 1999, a reflection, at least in part, of the effects of high oil prices. High prices also helped to stabilize domestic oil production in 2000 after several years of declines. With flat consumption and production, one would normally not expect such a strong increase in imports. The explanation lies in the fact that oil imports in 1999 were moderated by a considerable drawdown in oil inventories. With U.S. oil stocks near historically low levels by the end of 1999, a boost in oil imports was required just to keep consumption constant. Reflecting both higher quantities and prices, the value of U.S. oil imports grew 50 percent in $2000(\mathrm{Q} 4 / \mathrm{Q} 4)$.

\section{Non-Oil Imports}

The quantity of non-oil imports grew 11 percent in $2000(\mathrm{Q} 4 / \mathrm{Q} 4$, table 5). Reflecting the strength of spending by both households and businesses in the United States, the quantity of imported consumer goods (other than automotive products) rose 14 percent, and the quantity of imported capital equipment increased 20 percent. The slowdown in U.S. GDP growth that occurred during the second half of the year was reflected in a drop in the growth of goods imports from a pace of more than 15 percent at an annual rate during the first three quarters of the year to about zero growth in the fourth quarter. Imports of automotive products, which increased only $2^{1 / 2}$ percent during the year, turned down in the fourth quarter as U.S. sales of vehicles dropped back from the very high levels recorded earlier in the year. In addition, there were significant declines in the fourth quarter in the quantity of imported high-tech equipment and industrial supplies. Fourth-quarter increases were recorded for imports of other capital equipment and of consumer goods and services, albeit at a somewhat slower pace than in the first half of the year.

Overall, U.S. non-oil import prices rose $1 / 2$ percent in 2000 (table 6). When prices of computers and semiconductors are excluded, the import price increases were larger, $1 \frac{1}{2}$ percent. Much of the rise in these prices was attributable to industrial supplies, whose prices surged more than 10 percent, an increase led by prices of natural gas, paper, nonferrous metals, fertilizers, and organic chemicals. In contrast, prices of other imported goods, such as machinery other than computers and semiconductors and consumer goods, declined at rates of just over 1 percent in 2000, rates only slightly different from those recorded during the previous two years. The hedonic indexes of prices of computers and semiconductors continued to drop in 2000.

\section{DEVELOPMENTS IN THE NONTRADE CURRENT ACCOUNT}

The two major components of the current account other than trade in goods and services are investment income and unilateral transfers.

\section{Investment Income}

Net investment income is the difference between the income that U.S. residents earn on their holdings of 
6. U.S. net international investment: Position and receipts, 1980-2000

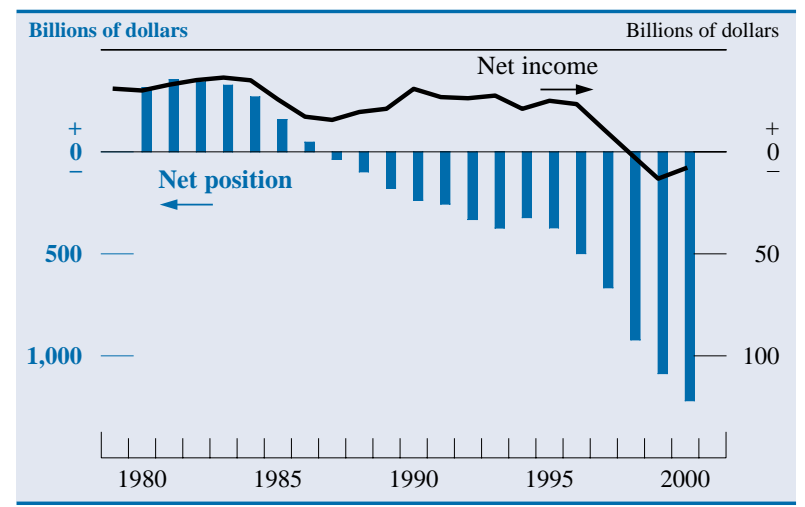

Note. The net position data are averages of the end-of-year positions for the current and previous years. The year-end position for 2000 was constructed by adding the recorded portfolio investment flows during 2000 to the recorded year-end position for 1999. The net position excludes U.S. gold holdings and foreign holdings of U.S. currency.

SourCE. U.S. Department of Commerce, Bureau of Economic Analysis; and the Federal Reserve Board.

foreign assets (receipts) and the income that foreigners earn on their holdings of U.S. assets (payments). Traditionally (since 1914), the balance on investment income has been positive, but starting in the early 1990s it began a persistent decline that brought it to near zero in 1998 and to negative $\$ 13$ billion in 1999 - a net payment position (chart 6). This recent decline in net investment income has resulted primarily from the fact that, over the period, the United States has experienced large net financial inflows from the rest of the world. That is, foreign acquisition of U.S. assets has vastly exceeded U.S. acquisition of foreign assets. Although the net financial asset position is the primary determinant of net investment income, changing rates of return on these assets also affect the balance. In 2000, net investment payments were $\$ 8$ billion, slightly less than in 1999 . Although large financial inflows last year tended to increase net payments, the inflows were more than offset by an increase in the rate of return on U.S. direct investment abroad and a decline in the rate of return on foreign direct investment in the United States.

\section{Direct Investment Income}

Net direct investment income-the difference between receipts from U.S. direct investment abroad and payments on foreign direct investment in the United States-increased almost 35 percent in 2000, to $\$ 84$ billion dollars. Direct investment receipts grew a robust 26 percent (table 7). Despite a slowdown in the last half of the year, payments grew 18 percent over 1999.

The growth in receipts reflected strong GDP growth abroad in the first three quarters of the year, a rising stock of direct investment capital, and the effects of high oil prices on the profitability of U.S.based international energy corporations. Receipts grew strongly despite the offsetting effect of the strength of the dollar vis-à-vis many of the important host countries for U.S. direct investment, which lowered the dollar value of profits earned in foreign currencies.

Major increases in direct investment receipts were registered for Western European countries, particularly the United Kingdom, and for Canada, Japan, and a number of other Asian countries. Receipts from Latin America were flat for the second straight year. Mirroring the overall strength of receipts, the rate of return on the direct investment position rose to $10 \frac{1}{2}$ percent-more than 1 percentage point higher than in 1999 (chart 7). ${ }^{1}$

Although income payments on direct investment in the United States, at $\$ 66$ billion for 2000, increased

1. In charts $6-9$, the investment receipts (or payments) scale is one-tenth of the investment position scale, and thus when the receipts (or payments) line coincides with the top of the position bar, the implied rate of return is 10 percent.

7. U.S. net investment income, 1995-2000

Billions of dollars

\begin{tabular}{|c|c|c|c|c|c|c|c|}
\hline Item & 1995 & 1996 & 1997 & 1998 & 1999 & 2000 & $\begin{array}{c}\text { Change, } \\
1999 \text { to } 2000\end{array}$ \\
\hline Investment income, net & 25 & 23 & 11 & -1 & -13 & -8 & 5 \\
\hline Direct investment income, net & 65 & 69 & 72 & 68 & 63 & 84 & 21 \\
\hline Receipts ............... & 95 & 103 & 116 & 106 & 119 & 149 & 31 \\
\hline Payments ............... & 30 & 33 & 44 & 39 & 56 & 66 & 10 \\
\hline Portfolio investment income, net & -40 & -46 & -61 & -69 & -76 & -92 & -16 \\
\hline Receipts... & 114 & 120 & 140 & 150 & 155 & 194 & 38 \\
\hline Payments ......................... & 154 & 166 & 201 & 219 & 231 & 286 & 55 \\
\hline
\end{tabular}

Source. U.S. Department of Commerce, Bureau of Economic Analysis, U.S. international transactions accounts. 
7. U.S. direct investment abroad: Position and receipts, 1980-2000

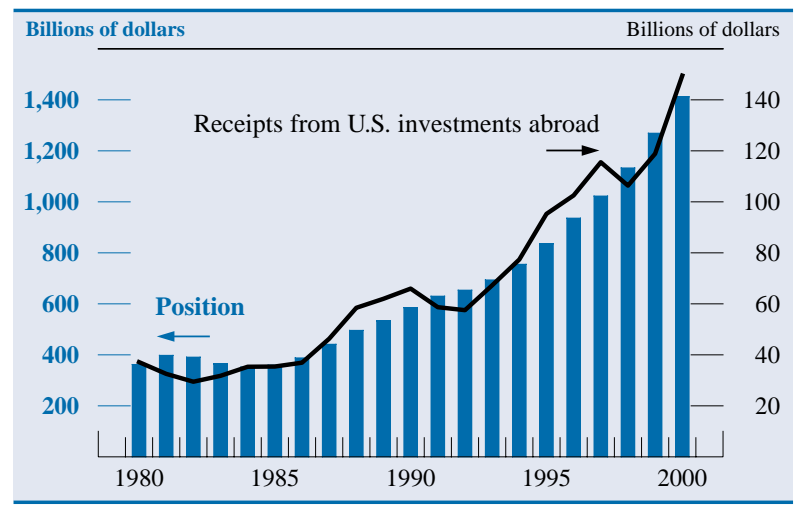

Note. The position data are averages using the current-cost measures as of year-end for the current and previous years. The year-end data for 2000 were constructed by adding the recorded direct investment capital flows and current cost adjustment during 2000 to the recorded year-end position for 1999 .

Source. U.S. Department of Commerce, Bureau of Economic Analysis; and the Federal Reserve Board.

significantly over 1999, the growth slowed considerably in the second half of 2000 as the U.S. economy cooled. The overall rate of return, at about 5 percent, was $1 / 4$ of a percentage point lower than that in 1999 (chart 8).

With the net direct investment position continuing its trend decline toward zero, the large positive balance on direct investment income was primarily the result of the long-standing higher rate of return on U.S. direct investment abroad than on foreign direct investment in the United States. The reasons for the differential in the rates of return are not well understood, but age-related factors appear to be important: Foreign direct investment in the United States is

8. Foreign direct investment in the United States: Position and payments, 1980-2000

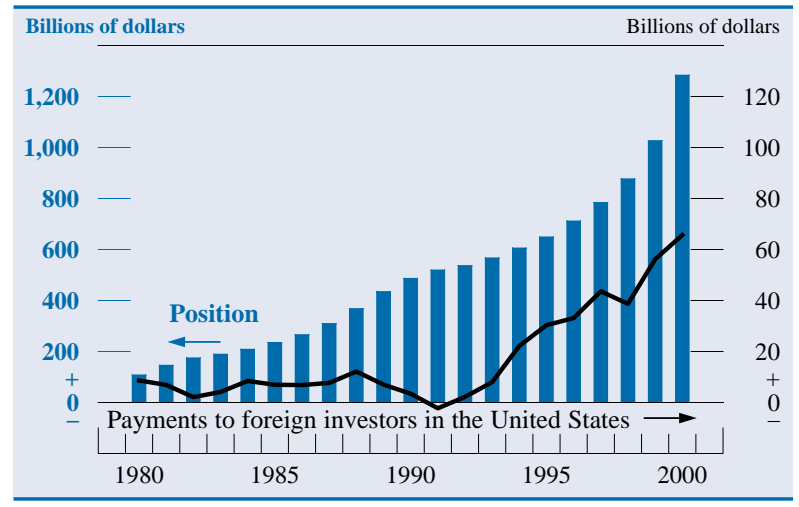

NotE. The position data are averages using the current-cost measures as of year-end for the current and previous years. The year-end data for 2000 were constructed by adding the recorded direct investment capital flows and currentcost adjustment during 2000 to the recorded year-end position for 1999.

SourCE. U.S. Department of Commerce, Bureau of Economic Analysis; and the Federal Reserve Board. typically newer than U.S. direct investment abroad and hence is more likely to be incurring startup and restructuring costs and less likely to have fully realized the gains from operational experience.

\section{Portfolio Investment Income}

Portfolio receipts reflect the dividends and interest that U.S. residents receive on their holdings of foreign financial assets, whereas payments reflect the dividends and interest that foreigners receive on their holdings of U.S. financial assets. The Bureau of Economic Analysis (BEA) estimates these payments and receipts by using estimates of the holdings of various types of assets combined with estimates of the interest or dividend-payout rates for the various assets. Portfolio income excludes any capital gains or losses (realized or not) that result from changes in the price of the underlying assets.

Although portfolio income is affected by changes in interest rates and the composition of the assets held, the primary determinant of net portfolio payments is the net portfolio asset position, which is illustrated in chart 9. As shown in the chart, net portfolio income turned negative in 1985 when the net investment position moved from one of net creditor to net debtor, and it has followed the general contour of the net investment position since. Between 1999 and 2000, net income declined \$15 billion, to negative $\$ 92$ billion. This decline reflects a further deterioration of the net asset position as well as a

9. Net portfolio investment: Position and receipts, 1980-2000

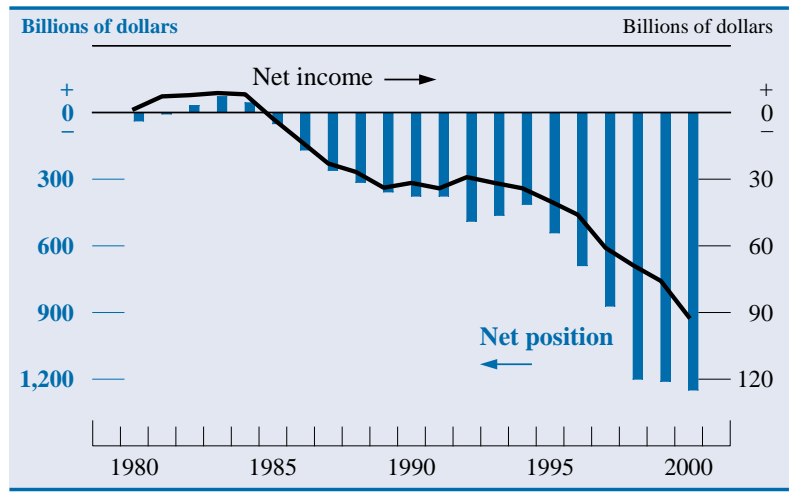

Note. The net position data are Federal Reserve Board estimates of the average position during the year. Through 1999 these are based on quarterly financial flows and year-end position estimates published by the BEA. For 2000, the average is based on year-end 1999 position data and quarterly financial flows during 2000. The net position excludes U.S. gold holdings and foreign holdings of U.S. currency.

SourCE. U.S. Department of Commerce, Bureau of Economic Analysis; and the Federal Reserve Board. 
general increase in interest rates, which raised the rate of return on portfolio assets.

\section{Unilateral Transfers}

Unilateral transfers include government grant and pension payments as well as private transfers to and from foreigners. In 2000, net unilateral transfers recorded a deficit of $\$ 52$ billion, $\$ 4$ billion more than in 1999. About half the increase was in private remittances, and half was in government grants.

\section{FINANCIAL AND CAPITAL ACCOUNT TRANSACTIONS}

The counterpart to the increase in the U.S. current account deficit in 2000 was an increase in net financial inflows. As in 1999, U.S. financial flows in 2000 reflected the relatively strong cyclical position of the U.S. economy and the global wave of corporate mergers. Foreign private purchases of U.S. securities were exceptionally strong - well in excess of the record set in 1997.

The composition of U.S. securities purchased by foreigners continued the shift away from Treasuries that began in 1999, as the U.S. budget surplus and the attendant decline in the supply of Treasuries lowered their yield relative to that of other debt securities. Last year sales by private foreigners were, on net, $\$ 52$ billion in Treasury securities, compared with net sales of $\$ 21$ billion in 1999 (table 8). Although sizable, these sales were slightly less than they would have been had foreigners reduced their holdings in proportion to the reduction in Treasuries outstanding. The increased sale of Treasuries was fully offset by larger foreign purchases of U.S. securities issued by government-sponsored agencies. Net purchases of agency securities topped $\$ 110$ billion, compared with the record $\$ 72$ billion set in 1999 . In contrast to the shrinking supply of Treasury securities, U.S.government-sponsored agencies accelerated the pace of their debt issuance. Private foreign purchases of U.S. corporate and other bonds (including agencies) grew to a record $\$ 294$ billion, while net purchases of U.S. equities ballooned from $\$ 99$ billion in 1999 to $\$ 172$ billion.

The pace of foreign direct investment inflows also accelerated from the record pace of 1999. As in the previous two years, direct investment inflows were driven by foreign acquisition of U.S. firms, which reflected the global strength in merger and acquisi-

8. Composition of U.S. financial flows, 1995-2000

Billions of dollars

\begin{tabular}{|c|c|c|c|c|c|c|}
\hline Item & 1995 & 1996 & 1997 & 1998 & 1999 & 2000 \\
\hline Current account balance & -110 & -123 & -141 & -217 & -332 & -435 \\
\hline Official financial flows, net & 99 & 132 & 18 & -27 & 54 & 35 \\
\hline Foreign official assets in the United States & 110 & 127 & 19 & -20 & 43 & 36 \\
\hline U.S. official reserve assets .............. & -10 & 7 & -1 & -7 & 9 & 0 \\
\hline Other U.S. government assets ..... & -1 & -1 & 0 & 0 & 3 & -1 \\
\hline Private financial flows, net & 14 & 25 & 250 & 174 & 269 & 364 \\
\hline $\begin{array}{l}\text { Net inflows reported by U.S. banking offices } \\
\text { Securities transactions, net .................. }\end{array}$ & $\begin{array}{r}-45 \\
73\end{array}$ & $\begin{array}{l}-75 \\
135\end{array}$ & $\begin{array}{r}8 \\
225\end{array}$ & $\begin{array}{r}4 \\
131\end{array}$ & $\begin{array}{r}-3 \\
183\end{array}$ & -31 \\
\hline Private foreign net purchases of U.S. securities & 196 & 285 & 344 & 267 & 311 & 414 \\
\hline Treasury securities ................................ & 100 & 155 & 146 & 49 & -21 & $\begin{array}{l}114 \\
-52\end{array}$ \\
\hline Corporate and other bonds ….......... & 83 & 119 & 128 & 172 & 233 & 294 \\
\hline Corporate stocks .......... & 14 & 11 & 70 & 46 & 99 & 172 \\
\hline U.S. net purchases of foreign securities & -123 & -150 & -119 & -136 & -129 & -124 \\
\hline 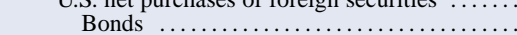 & -57 & -67 & -61 & $\begin{array}{r}-130 \\
-35\end{array}$ & -14 & -25 \\
\hline Stocks & -65 & -83 & -58 & -101 & -114 & -99 \\
\hline $\begin{array}{l}\text { Stock swaps } \\
\text { Stock.... }\end{array}$ & $\begin{array}{r}-03 \\
-7\end{array}$ & $\begin{array}{l}-83 \\
-11\end{array}$ & $\begin{array}{r}-58 \\
-3\end{array}$ & $\begin{array}{r}-101 \\
-96\end{array}$ & $\begin{array}{l}-114 \\
-123\end{array}$ & $\begin{array}{l}-99 \\
-80\end{array}$ \\
\hline Direct investment, net & -41 & -5 & 1 & 40 & 125 & 155 \\
\hline Foreign direct investment in the United States & 58 & 87 & 106 & 186 & 276 & 317 \\
\hline U.S. direct investment abroad ............... & -99 & -92 & -105 & -146 & -151 & -162 \\
\hline Foreign holdings of U.S. currency & 12 & 17 & 25 & 17 & 22 & 1 \\
\hline Other & 14 & -47 & -9 & -18 & -58 & -51 \\
\hline Capital account balance & $\mathbf{0}$ & 1 & $\mathbf{0}$ & 1 & -4 & 1 \\
\hline Statistical discrepancy & -4 & -35 & -128 & 70 & 12 & 36 \\
\hline
\end{tabular}

SourCE. U.S. Department of Commerce, Bureau of Economic Analysis, U.S. international transactions accounts. 
tion activity. Of the $\$ 317$ billion in direct investment inflows in 2000, almost $\$ 200$ billion was directly attributable to merger activity. Many of these mergers were financed, at least in part, by an exchange of equity, in which shares in the U.S. firm were swapped for equity in the acquiring firm. Although U.S. residents generally appear to have sold a portion of the equity acquired through these swaps, the swaps likely contributed significantly to the $\$ 124$ billion capital outflow attributed to U.S. acquisition of foreign securities. U.S. direct investment abroad was also boosted by merger activity and totaled $\$ 162$ billion in 2000 — a modest increase over 1999.

Financial inflows from foreign official sources totaled $\$ 36$ billion in 2000 - a slight decrease from 1999. Nearly all of the official inflows were attributable to reinvested interest earnings. Modest official sales of dollar assets associated with foreign exchange intervention were offset by larger inflows from some non-OPEC oil exporting countries, which benefited from the elevated price of oil. U.S. government assets abroad (official and other) were little changed on balance last year.

Capital account transactions-which consist mainly of debt forgiveness and wealth transfers asso- ciated with immigration-netted to positive $\$ 1$ billion last year. In 1999, they were negative $\$ 4$ billion, most of which reflected the transfer of the Panama Canal to the Republic of Panama.

\section{PROSPECTS FOR 2001}

Opposing forces have been at work on the U.S. current account balance since late 2000. The continued appreciation of the dollar into the first few months of 2001 will tend to increase the goods and services trade deficit this year as the adjustment process unfolds. In addition, the ongoing deterioration of the U.S. net international investment position will tend to increase the deficit on investment income. However, domestic spending growth appears to have slowed more sharply than foreign spending growth recently, which puts more downward pressure on the growth rate of imports than on that of exports. If these circumstances persist, the current account deficit is likely to change much less in 2001 than it did in 2000. 